\title{
Urgensi Manajemen Pengawasan Risiko Bank Syariah
}

\author{
Oleh: \\ Rusdan \\ Jurusan Ekonomi Syariah Fakultas Ekonomi Islam IAI Nurul Hakim \\ e-mail: rusdan1983@gmail.com
}

\begin{abstract}
ABSTRAK
Perbankan, tak terkecuali Bank Syariah, memiliki posisi strategis sebagai lembaga intermediasi dan penunjang sistem pembayaran. Sebagai lembaga intermediasi, perbankan dapat memberikan kemudahan untuk mengalirkan dana dari pihak yang memiliki kelebihan dana (savers) dengan kedudukan sebagai penabung ke pihak yang memerlukan dana (borrowers) untuk berbagai kepentingan. Selain itu, bank juga sebagai agent of development, yang dapat mendorong kemajuan pembangunan melalui fasilitas kredit dan kemudahan-kemudahan pembayaran dan penarikan dalam proses transaksi yang dilakukan para pelaku ekonomi.

Dalam melakukan fungsinya tersebut, sektor perbankan memiliki eksposur terhadap berbagai macam risiko. Untuk dapat menjalankan fungsinya dengan baik, sektor perbankan dituntut untuk mampu secara efektif mengelola risiko-risiko yang dihadapinya agar dapat memelihara kesinambungan proses bisnisnya sehingga proses intermediasi keuangan dalam perekonomian dapat berkelanjutan dan berjalan dengan efisien.

Ada beberapa macam risiko yang perlu diidentifikasi, diukur, dipantau, dan dikendalikan oleh perbankan syariah dalam menjalankan kegiatan usahanya meliputi: risiko pembiayaan (financing risk), risiko pasar (market risk), risiko likuiditas (liquidity risk), risiko operasional (operational risk), risiko hukum (legal risk), risiko reputasi (reputation risk), risiko strategis (strategic risk), risiko kepatuhan (compliance risk) dan sebagainya.
\end{abstract}

Kata Kunci: Bank syariah, risiko, intermediasi.

\section{A. Pendahuluan}

Meskipun manajer bank berusaha untuk menghasilkan keuntungan setinggi-tingginya, secara simultan mereka juga harus memperhatikan kemungkinan adanya risiko yang timbul menyertai keputusan-keputusan manajemen tentang struktur aset dan liabilitasnya. Secara spesifik risiko-risiko yang akan menyebabkan bervariasinya tingkat keuntungan bank meliputi, diantaranya: risiko likuiditas, risiko kredit, risiko tingkat bunga, dan risiko modal. Bank syariah tidak akan menghadapi risiko tingkat bunga secara langsung, walaupun dalam lingkungan di mana berlaku dual banking system meningkatnya tingkat bunga di pasar konvensional dapat berdampak pada meningkatnya risiko 
likuiditas sebagai akibat adanya nasabah yang menarik dananya dari bank syariah dan berpindah ke bank konvensional. ${ }^{1}$

Risiko dalam konteks perbankan merupakan kejadian potensial, baik yang dapat diperkirakan (anticipated) maupun yang tidak dapat diperkirakan (unanticipated) yang berdampak negatif terhadap pendapatan dan permodalan bank. Risiko-risiko tersebut tidak dapat dihindari, tetapi dapat dikelola dan dikendalikan. Oleh karena itu, sebagaimana lembaga perbankan pada umumnya, bank syariah juga memerlukan serangkaian prosedur dan metodologi yang dapat digunakan untuk mengidentifikasi, mengukur, memantau, dan mengendalikan risiko yang timbul dari kegiatan usaha, atau yang biasa disebut sebagai manajemen risiko.

Sasaran kebijakan manajemen risiko adalah mengindentifikasi, mengukur, memantau, dan mengendalikan jalannya kegiatan usaha bank dengan tingkat risiko yang wajar secara terarah, terintegrasi, dan berkesinambungan. Dengan demikian, manajemen risiko berfungsi sebagai filter atau pemberi peringatan dini (early warning system) terhadap kegiatan usaha bank. Secara umum, tujuan manajemen risiko itu sendiri adalah sebagai berikut:

Menyediakan informasi tentang risiko kepada pihak regulator.

Memastikan bank tidak mengalami kerugian yang bersifat unacceptable.

Meminimalisasi kerugian dari berbagai risiko yang bersifat uncontrolled.

Mengukur eksposur dan pemusatan risiko.

Mengalokasikan modal dan membatasi risiko. ${ }^{2}$

\section{B. Pengertian Risiko}

Ada banyak definisi mengenai risiko (risk). Menurut Ricky W. Griffin dan Ronald J. Ebert risiko adalah uncertanty about future events. Sementara Joel G. Siegel

${ }^{1}$ Muhammad, Manajemen Bank Syariah, (Yogyakarta: UPP AMP YKPN, 2005), hal. 357; Nur Kholis, "Transaksi dalam Ekonomi Islam”, Modul, Yogyakarta: MSI UII, 2006, hal. 101-102.

2 Adiwarman A. Karim, Bank Syariah Analisis Fiqih dan Keuangan, (Jakarta: PT. RajaGrafindo Persada, 2008), hal. 255.

86 P A $\mathcal{L} \mathcal{A} P \mathcal{A}$ : Jurnal Studi Keislaman dan Ilmu Pendidikan | Volume 4 Nomor 2 (2016) November 
dan Jae K. Shim mendefinisikan risiko pada tiga hal, pertama adalah keadaan yang mengarah kepada sekumpulan hasil khusus, di mana hasilnya dapat diperoleh dengan kemungkinan yang telah diketahui oleh pengambil keputusan. Kedua, adalah variasi dalam keuntungan, penjualan, atau variabel keuangan lainnya, dan ketiga adalah kemungkinan dari sebuah masalah keuangan yang mempengaruhi kinerja operasi perusahaan atau posisi keuangan, seperti risiko ekonomi, ketidakpastian politik, dan masalah industri. ${ }^{3}$

Sementara Gulatti mengatakan bahwa risiko adalah suatu kondisi yang memungkinkan terjadinya kerugian. Di lain pihak, Badan Sertifikasi Manajemen Risiko mengartikan risiko sebagai kemungkinan akan terjadinya hasil yang tidak diinginkan yang dapat menimbulkan kerugian apabila tidak diantisipasi serta tidak dikelola dengan semestinya. ${ }^{4}$

\section{Urgensi Manajemen dalam Islam}

Mengacu pada Kamus Ilmiah Populer, ${ }^{5}$ manajemen secara umum didefinisikan sebagai pengelolaan usaha; kepengurusan; ketatalaksanaan penggunaan sumber daya secara efektif untuk mencapai sasaran yang diinginkan; dan direksi.

Sementara itu, R Terry mendefinisikannya sebagai suatu proses khas yang terdiri dari tindakan-tindakan perencanaan, pengorganisasian, penggerakan dan pengendalian yang dilakukan untuk menentukan serta mencapai sasaran-sasaran yang telah ditentukan melalui pemanfaatan sumber daya manusia dan sumbersumber lainnya. ${ }^{6}$

Senada dengan definisi yang dikemukakan Terry tersebut, Muslich ${ }^{7}$ mengartikan manajemen sebagai suatu cara atau metode yang konseptual

${ }^{3}$ Irham Fahmi, dkk, Studi Kelayakan Bisnis Teori dan Aplikasi, (Bandung: Alfabeta, 2009), hal. 87.

${ }^{4}$ Sri Indah Nikensari, Perbankan Syariah Prinsip, Sejarah, dan Aplikasinya, (Semarang: Pustaka Rizki Putra, 2012), hal. 169-170.

${ }^{5}$ Pius A Partanto dan M. Dahlan al Barry, Kamus Ilmiah Populer, (Surabaya: Penerbit Arkola, tt), h. 434. 2004), h. 7.

${ }^{6}$ Amirullah dan Haris Budiyono, Pengantar Manajemen, (Yogyakarta: Graha Ilmu,

Muslich, Bisnis Syariah Perspektif Mu'amalah dan Manajemen, (Yogyakarta: UPP STIM YKPN, 2007), h. 115.

$87 \mathscr{P} \mathcal{L} \mathcal{L} \mathcal{A} P \mathcal{A}:$ Jurnal Studi Keislaman dan Ilmu Pendidikan | Volume 4 Nomor 2 (2016) November 
mengenai pemberdayaan atas sumber daya secara keseluruhan yang operasionalisasinya dilaksanakan secara terencana, terorganisasi, tertib, terkoordinasi, serta terkendali sehingga tujuan atau sasaran dapat tercapai secara efektif dan efisien. Efisien mengandung arti mengerjakan sesuatu dengan benar (doing things right), sedangkan efektif berarti mengerjakan sesuatu yang benar (doing the right things). Dalam bahasa yang lebih sederhana efisiensi itu menunjukkan kemampuan organisasi dalam menggunakan sumber daya dengan benar dan tidak ada pemborosan. Setiap perusahaan akan berusaha mencapai tingkat output dan imput yang seoptimal mungkin.

Sebaliknya, efektivitas menunjukkan kemampuan suatu perusahaan dalam mencapai sasaran-sasaran (hasil akhir) yang telah ditetapkan secara tepat. Pencapaian hasil akhir yang sesuai dengan target waktu yang telah ditetapkan tersebut telah memperhatikan efektivitas operasionalnya. Dengan demikian, antara efektivitas dan efisiensi itu saling terkait. ${ }^{8}$ Apalah artinya manajemen dalam sebuah organisasi jika tidak menjadikan organisasi itu efisien dan efektif dalam melaksanakan tugasnya. Jika pemimpin telah memberikan delegasi kepada bawahannya untuk melaksankan sebuah tugas, tetapi bawahan itu selalu melapor setiap waktu, hal ini menandakan tidak berjalannya manajemen karena salah satu fungsi manajemen adalah memberikan delegasi dan wewenang kepada bawahan.

Dalam kenyataannya, tipe pemimpin turut menentukan efisiensi dan efektivitas suatu organisasi. Pemimpin yang baik mampu mendelegasikan tugas dan wewenang kepada bawahannya, sehingga seorang bawahan mampu melakukan sesuatu secara kreatif tanpa harus terus-menerus melapor kepadanya.'

Sementara itu, definisi manajemen dalam Islam tidak jauh dari pemahaman tersebut di atas. Manajemen dianggap sebagai ilmu sekaligus teknik (seni) kepemimpinan di awal perkembangan Islam. Akan tetapi, pemikiran manajemen telah diterapkan dalam beberapa negara yang tersebar di penjuru dunia sebelum masa Islam.

\footnotetext{
${ }^{8}$ Amirullah dan Haris Budiyono, Op. Cit., h. 8.

${ }^{9}$ Didin Hafidhuddin dan Hendri Tanjung, Manajemen Syariah dalam Praktik, (Jakarta: Gema Insani Press, 2003), h. 11-12.
} 
Kristalisasi pemikiran manajemen dalam Islam muncul setelah Allah menurunkan risalah-Nya kepada Muhamad Saw, Nabi dan Rasul akhir zaman. Pemikiran manajemen dalam Islam bersumber dari nash-nash al-Qur'an dan petunjuk-petunjuk sunnah. Selain itu, ia juga berasaskan pada nilai-nilai kemanusiaan yang berkembang dalam masyarakat pada waktu tersebut (al-urf). Berbeda dengan manajemen konvensional, ia merupakan suatu sistem yang aplikasinya bersifat bebas nilai serta hanya berorientasi pada pencapaian manfaat duniawi semata. Manajemen ini berusaha untuk diwarnai dengan nilai-nilai, namun dalam perjalannya tidak mampu. Karena ia tidak bersumber dan berdasarkan petunjuk syariah yang bersifat sempurna, komprehensif dan syarat kebenaran. $^{10}$

Sebenarnya terdapat perbedaan mendasar antara manajemen syariah (Islam) dengan manajemen modern. Keduanya berbeda dalam hal tujuan, bentuk, aturan teknis, penyebarluasan, dan disiplin keilmuan. Di samping itu, pengembangan pemikiran manajemen modern oleh negara barat telah berlangsung sangat dinamis. Di satu sisi, masyarakat Muslim belum optimal dalam mengembangkan kristalisasi pemikiran manajemen syariah dari peninggalan sejarah (turats) yang otentik, baik dari segi teori ataupun praktik. Padahal Rasulullah telah bersabda bahwa, "Telah aku tinggalkan atas kalian semua suatu perkara, jika kalian berpegang teguh atasnya, maka kalian tidak akan tersesat selamanya setelabku, yaitu kitab Allah (al-Qur'an) dan sunnabkeu (al-Hadis)"11

Perbedaan mendasar antara manajemen konvensional dengan manajemen syariah dapat dilihat dari segi prinsip-prinsip yang melandasinya, seperti:

1. Prinsip amar ma'ruf nabi mungkar.

2. Kewajiban menegakkan kebenaran.

3. Kewajiban menegakkan keadilan.

4. Kewajiban menyampaikan amanah. ${ }^{12}$

10 Ahmad Ibrahim Abu Sinn, Manajemen Syariah Sebuah Kajian Historis dan Kontemporer, (Jakarta: PT. RajaGrafindo Persada, 2008), h. 28.

${ }^{11}$ Ibid., h. 30 .

12 Uraian selengkapnya baca Zainul Arifin, Dasar-dasar Manajemen Bank Syariah, (Jakarta: Alvabet, 2006), h. 87-90.

89 P A $\mathcal{L} \mathcal{A} P \mathcal{A}$ : Jurnal Studi Keislaman dan Ilmu Pendidikan | Volume 4 Nomor 2 (2016) November 


\section{Jenis-Jenis Risiko dalam Bank Syariah}

Perbankan adalah lembaga yang paling dekat dengan risiko, khususnya yang berkaitan dengan uang. Posisi bank sebagai mediator telah menempatkannya sebagai pihak yang paling begitu riskan dalam urusan risiko. Berfluktuasinya kondisi perekonomian baik domestik, regional, maupun internasional turut memberi andil dalam urusan pembentukan risiko perbankan. ${ }^{13}$ Secara umum, risiko yang mungkin dihadapi bank meliputi risiko kredit/pembiayaan (credit/financing risk), risiko pasar (market risk), risiko likuiditas (liquidity risk), risiko operasional (operational risk), risiko hukum (legal risk), risiko reputasi (reputation risk), risiko strategis (strategic risk), risiko kepatuhan (compliance risk), dan sebagainya. Berbagai jenis risiko tersebut dapat dibedakan menjadi dua kelompok besar, yakni (1) risiko yang sistemik (systemic risk), yakni risiko yang diakibatkan oleh adanya kondisi atau situasi tertentu yang bersifat makro, seperti perubahan situasi politik, perubahan kebijakan ekonomi pemerintah, perubahan situasi pasar, situasi krisis atau resesi, dan sebagainya yang berdampak pada kondisi ekonomi secara umum; dan (2) risiko yang tidak sistemik (unsystemic risk), yaitu risiko yang unik, yang melekat pada suatu perusahaan atau bisnis tertentu saja. ${ }^{14}$

\section{Risiko Pembiayaan (Financing Risk).}

Risiko pembiayaan adalah risiko akibat kegagalan nasabah atau pihak lain dalam memenuhi kewajiban kepada bank sesuai dengan perjanjian yang telah disepakati. ${ }^{15}$ Risiko pembiayaan ini merupakan salah satu risiko utama dalam pemberian pembiayaan bank syariah. ${ }^{16}$

Risiko pembiayaan muncul jika bank tidak bisa memperoleh kembali cicilan pokok dan/ atau bagi hasil/margin fee dari pinjaman yang diberikannya atau investasi yang sedang dilakukannya.

Penyebab utama terjadinya risiko pembiayaan ini adalah terlalu mudahnya bank memberikan pinjaman atau melakukan investasi karena

${ }^{13}$ Irham Fahmi, dkk, Op. Cit., hal. 86.

${ }^{14}$ Zainul Arifin, Op. Cit., hal. 225.

${ }^{15}$ Sri Indah Nikensari, Op. Cit., hal. 174. Lihat juga Dadan Muttaqien dan Fakhruddin Cikman, Penyelesaian Sengketa Bank Syariah, (Yogyakarta: Total Media, 2008), hal. 40-41.

${ }^{16}$ Heri Sudarsono dan Hendi Yogi Prabowo, Istilah-Istilah Bank dan Lembaga Keuangan Syariah, (Yogyakarta: UII Press, 2006), hal. 139.

90 P A $\mathcal{L} \mathcal{A} P \mathcal{A}:$ Jurnal Studi Keislaman dan Ilmu Pendidikan | Volume 4 Nomor 2 (2016) November 
terlalu dituntut untuk memanfaatkan kelebihan likuiditas, sehingga penilaian pembiayaan kurang cermat dalam mengantisipasi berbagai kemungkinan risiko usaha yang dibiayainya.

Risiko ini akan semakin tampak ketika perekonomian dilanda krisis atau resesi. Turunnya penjualan mengakibatkan berkurangnya penghasilan perusahaan, sehingga perusahaan mengalami kesulitan untuk memenuhi kewajiban membayar utang-utangnya. Ketika bank akan mengeksekusi kredit macetnya, bank tidak memperoleh hasil yang memadai, karena jaminan yang ada tidak sebanding dengan besarnya pembiayaan yang diberikannya. Pada akhirnya, bank akan mengalami kesulitan likuiditas yang berat, terutama ketika ia mempunyai pembiayaan macet yang cukup besar.

Risiko tersebut dapat ditekan dengan cara memberi batas wewenang keputusan pembiayaan bagi setiap aparat yang membidangi pembiayaan, berdasarkan kapabilitasnya (autorize limit) dan batas jumlah (pagu) pembiayaan yang dapat diberikan pada usaha atau perusahaan tetentu (financing line limit), melakukan diversifikasi, ${ }^{17}$ serta kebijakan agunan yang memadai. ${ }^{18}$

Dalam perbankan konvensional, pengelolaan terhadap risiko kredit ini antara lain menggunakan:

$\checkmark$ Collateral (jaminan).

$\checkmark$ Pricing (higher margin for higher risk).

$\checkmark$ Diversification (wide geographical and industrial speed).

$\checkmark$ Client credit rating. ${ }^{19}$

\section{Risiko Pasar (Market Risk).}

Risiko pasar adalah risiko kerugian yang terjadi pada portofolio yang dimiliki oleh bank akibat adanya pergerakan variabel pasar (adverse movement) berupa suku bunga dan nilai tukar. ${ }^{20}$ Namun begitu, bank syariah tidak mengenal risiko suku bunga, sehingga bank tidak mengalami risiko yang

${ }^{17}$ Zainul Arifin, Op. Cit., hal. 225-226; Muhammad, Op. Cit., hal. 358-359.

${ }^{18}$ Nur Kholis, Op. Cit., hal. 103.

${ }^{19}$ Sri Indah Nikensari, Op. Cit., hal. 185.

${ }^{20}$ Adiwarman A. Karim, Op. Cit., hal. 272.

$91 \mathcal{P} \mathcal{L} \mathcal{A} \mathcal{A} P \mathcal{A}:$ Jurnal Studi Keislaman dan Ilmu Pendidikan | Volume 4 Nomor 2 (2016) November 
berhubungan dengan suku bunga ini. Oleh karena itu, bank syariah hanya perlu mengelola risiko pasar yang terkait dengan perubahan nilai tukar yang dapat menyebabkan kerugian bank syariah. ${ }^{21}$

Risiko pasar ini mencakup empat hal, yaitu risiko tingkat suku bungan (interest rate risk), risiko pertukaran mata uang (foreign exchange risk), risiko harga (price risk), dan risiko likuiditas (liquidity risk). ${ }^{22}$

Risiko nilai tukar valuta asing (foreign exchange risk) timbul bila bank mengambil posisi terbuka (open position). Di saat bank berada pada posisi beli (overbought position/ long position), kerugian akan terjadi bila nilai tukar mata uang lokal (currency base) cenderung naik (menguat), dan sebaliknya pada saat bank berada pada posisi jual (oversold position/ short position), kerugian akan terjadi apabila mata uang lokal cenderung turun (melemah). Risiko nilai tukar valuta asing ini dapat ditekan dengan cara membatasi atau memperkecil posisi, atau bahkan dapat dihindari sama sekali bila bank selalu mengambil posisi squaire.

Pada umumnya, bank syariah lebih mampu menghindari risiko nilai tukar valuta asing, karena mereka dituntut untuk mematuhi norma-norma syariah yang antara lain adalah:

$\checkmark$ Bank syariah hanya melakukan transaksi komersil dan tidak akan pernah melakukan transaksi arbitrage.

$\checkmark$ Bank syariah hanya melakukan pertukaran valuta asing secara tunai.

$\checkmark$ Bank syariah tidak melakukan short selling.

$\checkmark$ Bank syariah tidak akan melakukan pertukaran tanpa penyerahan (non delivery trading). ${ }^{23}$

\section{Risiko Likuiditas (Liquidity Risk).}

Pemicu utama kebangkrutan bank, baik yang besar maupun kecil, bukan karena kerugian yang dideritanya, melainkan lebih pada ketidakmampuannya memenuhi kebutuhan likuiditas.

${ }^{21}$ Sri Indah Nikensari, Op. Cit., hal. 188-189.

${ }^{22}$ Adiwarman A. Karim, Loc. Cit.

${ }^{23}$ Zainul Arifin, Loc. Cit. 
Likuiditas secara umum dapat didefinisikan sebagai kemampuan untuk memenuhi kebutuhan dana (cash flow) dengan segera dan dengan biaya yang sesuai. Likuiditas penting bagi bank untuk menjalankan transaksi bisnisnya sehari-hari, mengatsi kebutuhan dana yang mendesak, memuaskan permintaan nasabah akan pinjaman dan memberikan fleksibilitas dalam meraih kesempatan investasi menarik dan menguntungkan.

Likuiditas yang tersedia harus cukup, tidak boleh terlalu kecil sehingga mengganggu kebutuhan operasional sehari-hari, tapi juga tidak boleh terlalu besar karena akan menurunkan efisiensi dan berdampak pada rendahnya tingkat profitabilitas.

Risiko likuiditas muncul manakala bank tidak mampu memenuhi kebutuhan dana (cash flow) dengan segera dan dengan biaya yang sesuai, baik untuk memenuhi kebutuhan transaksi sehari-hari maupun guna memenuhi kebutuhan dana yang mendesak. Besar kecilnya risiko ini ditentukan oleh:

$\checkmark$ Kecermatan perencanaan arus kas (cash flow) atau arus dana (fund flow) berdasarkan prediksi pembiayaan dan prediksi pertumbuhan dana, termasuk mencermati tingkat fluktuasi dana (volatility of funds).

$\checkmark$ Ketepatan dalam mengatur struktur dana, termasuk kecukupan danadana non bagi hasil.

$\checkmark$ Ketersediaan aset yang siap dikonversikan menjadi kas.

$\checkmark$ Kemampuan menciptakan akses ke pasar antar bank atau sumber dana lainnya, termasuk fasilitas lender of last resort (pemberi pinjaman terakhir). ${ }^{24}$

Secara garis besar, risiko likuiditas dalam operasioanal bank syariah terjadi karena:

a) Bank syariah kesulitan mencari dana cash dengan biaya yang wajar, baik lewat pinjaman maupun penjualan aset. Karena bunga atas pinjaman dilarang, maka bank syariah sulit mendapatkan pinjaman.

b) Larangan menjual surat utang selain pada nilai nominalnya, membuat bank syariah kesulitan likuiditas. ${ }^{25}$

${ }^{24}$ Zainul Arifin, Ibid., hal. 227-228; Muhammad, Op. Cit., hal. 359-360. 
Sementara itu, wujud risiko likuiditas yang mungkin dihadapi bank syariah mencakup:

$\checkmark$ Turunnya kepercayaan nasabah terhadap sistem perbankan, khususnya perbankan syariah.

$\checkmark$ Turunnya kepercayaan nasabah pada bank syariah yang bersangkutan.

$\checkmark$ Ketergantungan pada sekelompok deposan.

$\checkmark$ Dalam kontrak mudharabah, memungkinkan nasabah untuk menarik dananya kapan saja, tanpa pemberitahuan terlebih dahulu.

$\checkmark$ Mismatching antara dana jangka pendek dengan pembiayaan jangka panjang.

$\checkmark$ Keterbatasan instrumen keuangan untuk solusi likuiditas.

$\checkmark$ Bagi hasil antara bank kurang menarik, karena final settlment-nya harus menunggu selesainya perhitungan cash basis pendapatan bank yang biasanya baru terlaksana pada akhir bulan. ${ }^{26}$

\section{Risiko Nilai Tukar Valuta Asing (Foreigen Exchange Risk).}

Risiko pertukaran mata uang adalah suatu konsekuensi sehubungan dengan pergerakan atau fluktuasi nilai tukar terhadap rugi laba bank. Meskipun aktivitas tresuri syariah tidak terpengaruh kurs secara langsung karena adanya syarat tidak boleh melakukan transaksi yang bersifat spekulasi, tetapi bank syariah tidak akan dapat terlepas dari adanya posisi dalam valuta asing.

Ririko kurs ini akan meningkat bila jumlah posisi yang diambil besar, baik posisi long maupun short, dan fluktuasi pasar tinggi. Oleh karena itu, bank syariah perlu menetapkan exposure limit, transaction limit, currency limit, turnover limit, cut limit, intraday limit, dan counterparty limit.

Mengingat bank syariah tidak diperkenankan berspekulasi, maka transaksi seperti forward, margin trading, option, dan swap tidak boleh dijalankan. Yang diperkenankan adalah untuk kebutuhan transaksi atau berjaga-jaga (simpanan) dan transaksi yang dilakukan harus tunai atau spot. Termasuk

${ }^{25}$ Sri Indah Nikensari, Op. Cit., hal. 190.

${ }^{26}$ Adiwarman A. Karim, Op. Cit., hal. 275.

$94 \mathscr{\mathcal { A }} \mathcal{L} \mathcal{A} \mathscr{P} \mathcal{A}$ : Jurnal Studi Keislaman dan I Imu Pendidikan | Volume 4 Nomor 2 (2016) November 
tunai di sini adalah pembayaran dengan cek, pemindahbukuan, transfer dan sarana pembayaran tunai lainnya. ${ }^{27}$

\section{Risiko Operasional (Operational Risk).}

Risiko operasional adalah risiko yang antara lain disebabkan oleh ketidakcukupan atau tidak berfungsinya proses internal, buman error, kegagalan sistem atau adanya problem eksternal yang mempengaruhi operasional bank. ${ }^{28}$ Dengan kata lain, risiko operasional merupakan risiko yang menjadikan bank tidak dapat melakukan kegiatan operasionalnya secara normal karena adanya bencana alam, kebakaran, atau sebab-sebab lainnya, misalnya, penyusup (hacker) yang berhasil menyusup ke dalam pusat data bank dan mengacaukan data. Risiko ini juga mungkin terjadi karena adanya kesalahan dan penyalahgunaan wewenang (penyelewengan), ketidakpastian terhadap ketentuan atau kelemahan struktur pengendalian intern, dan prosedur yang tidak memadai, ataupun karena adanya gangguan pada sistem informasi manajemen, komunikasi, dan sistem pembayaran bank. ${ }^{29}$

Karena bank syariah relatif baru, maka faktor kesalahan manusia lebih mudah muncul. Penyebab lain misalnya software komputer yang tersedia di pasar tidak selalu kompatibel dengan bank syariah. ${ }^{30}$

Secara garis besar, ada tiga faktor yang menjadi penyebab timbulnya risiko ini, yaitu:

a. Infrastruktur, seperti teknologi, kebijakan, lingkungan, pengamanan, perselisihan, dan sebagainya.

b. Proses, dan

c. Sumber daya.

Risiko ini mencakup lima hal, yakni risiko reputasi (reputation risk), risiko kepatuhan (compliance risk), risiko transaksi (transactional risk), risiko strategis (strategic risk), dan risiko hukum (legal risk). ${ }^{31}$

${ }^{27}$ Adiwarman A. Karim, Ibid., hal. 273-274.

${ }^{28}$ Adiwarman A. Karim, Ibid., hal. 275; Sri Indah Nikensari, Op. Cit., hal. 192.

${ }^{29}$ Heri Sudarsono dan Hendi Yogi Prabowo, Op. Cit., hal. 140-141.

${ }^{30}$ Sri Indah Nikensari, Loc. Cit. 


\section{Risiko Hukum (Legal Risk).}

Kelemahan aspek yuridis dapat menimbulkan risiko adanya tuntutan hukum yang merugikan bank. Kelemahan itu antara lain dapat berupa ketiadaan peraturan perundang-undangan yang mendukung, atau kelemahan perikatan seperti tidak dipenuhinya syarat-syarat sahnya kontrak dan pengikatan agunan yang tidak sempurna. ${ }^{32}$

Bagi bank syariah sendiri, risiko hukum ini relatif teratasi, terutama pasca diterbitkannya Undang-undang No. 21 Tahun 2008 Tentang Perbankan Syariah. Kecuali itu, pihak yang berwenang pun telah menerbitkan serangkaian peraturan pelaksana dari undang-undang tersebut, sebut misalnya Peraturan Bank Indonesia No. 10/32/PBI/2008 Tentang Komite Perbankan Syariah, Peraturan Bank Indonesia No. 11/3/PBI/2009 Tentang Bank Umum Syariah, Peraturan Bank Indonesia No. 11/10/PBI/2009 Tentang Unit Usaha Syariah, Peraturan Bank Indonesia No. 11/15/PBI/2009 Tentang Perubahan Kegiatan Usaha Bank Konvensional Menjadi Bank Syaria, Peraturan Bank Indonesia No. 11/23/PBI/2009 Tentang Bank Pembiayaan Rakyat Syariah, dan sebagainya.

Dalam kaitannya dengan risiko hukum ini, hal-hal yang harus diperhatikan adalah:

$\checkmark$ Keharusan memiliki kebijakan dan prosedur secara tertulis.

$\checkmark$ Keharusan melaksanakan prosedur analisis aspek hukum terhadap produk dan aktifitas baru.

$\checkmark$ Keharusan memiliki satuan kerja yang berfungsi sebagai “legal watch", tidak saja terhadap hukum positif tetapi juga terhadap fatwa DSN dan ketentuan-ketentuan lainnya berdasarkan prinsip syariah.

$\checkmark$ Keharusan menilai dampak perubahan ketentuan/ peraturan terhadap risiko hukum.

$\checkmark$ Keharusan untuk menerapkan sanksi secara konsisten.

${ }^{31}$ Adiwarman A. Karim, Loc. Cit.

${ }^{32}$ Zainul Arifin, Op. Cit., hal. 233; Adiwarman A. Karim, Ibid., hal. 277. 
$\checkmark$ Keharusan untuk melakukan kajian secara berkala terhadap akad, kontrak, dan perjanjian-perjanjian bank dengan pihak lain dalam hal efektivitas dan enforceability. ${ }^{33}$

\section{Risiko Reputasi (Reputation Risk).}

Risiko reputasi antara lain disebabkan adanya publikasi negatif yang terkait dengan kegiatan usaha bank atau persepsi negatif terhadap bank. ${ }^{34}$ Hal-hal yang sangat berpengaruh terhadap reputasi antara lain:
a. Manajemen
b. Pemegang saham
c. Pelayanan yang disediakan
d. Penerapan prinsip-prinsip syariah
e. Publikasi

Bila manajemen dalam pandangan stakeholder dinilai baik, maka risiko reputasi menjadi rendah, demikian juga bila perusahaan dimiliki oleh pemegang saham yang kuat, maka risiko reputasi juga rendah. Dalam hal pelayanan, bila pelayanan kurang baik, maka risiko reputasi menjadi tinggi. Dalam penerapan prinsip-prinsip syariah haruslah dilakukan secara konsekuen agar tidak timbul penilaian negatif terhadap penerapan sistem syariah tersebut yang dapat mengakibatkan timbulnya publikasi negatif sehingga akan menaikkan tingkat risiko reputasi.

Ada beberapa hal yang menjadikan reputasi bank syariah menjadi turun, di antaranya:
a. Kesalahan manajemen
b. Melanggar peraturan
c. Melanggar fatwa DSN
d. Skandal keuangan
e. Kurang kompeten, baik dalam pengelolaan maupun pelayanan
f. Integritas yang diragukan

${ }^{33}$ Adiwarman A. Karim, Ibid., hal. 277-278.

${ }^{34}$ Zainul Arifin, Op. Cit., hal. 234; Sri Indah Nikensari, Op. Cit., hal. 194; Adiwarman A. Karim, Ibid., hal. 275.

$97 \mathscr{P} \mathcal{L} \mathcal{A} P \mathcal{A}$ : Jurnal Studi Keislaman dan I Imu Pendidikan | Volume 4 Nomor 2 (2016) November 
g. Performance keuangan yang kurang baik. ${ }^{35}$

\section{Risiko Strategis (Strategic Risk).}

Risiko strategis timbul karena adanya penetapan dan pelaksanaan strategi usaha bank yang tidak tepat, pengambilan keputusan bisnis yang yang tidak tepat, atau kurang responsifnya bank terhadap perubahanperubahan eksternal, ${ }^{36}$ semisal perubahan perundang-undangan dan ketentuan lain yang berlaku.

Indikasi dalam risiko strategis ini dapat dilihat dari kegagalan dalam mencapai target bisnis yang ditetapkan, baik target keuangan maupun nonkeuangan. ${ }^{37}$ Oleh karena itu, peran bagian perencanaan dan manajemen bank syariah harus lebih jeli melihat setiap strategi yang belum tepat. ${ }^{38}$

\section{Risiko Kepatuhan (Compliance Risk).}

Risiko kepatuhan timbul karena bank tidak mematuhi atau tidak melaksanakan peraturan perundang-undangan dan ketentuan-ketentuan lain yang berlaku. Pengelolaan risiko kepatuhan dilakukan melalui penerapan sistem pengendalian intern secara konsisten. ${ }^{39}$

Sementara itu, ketentuan-ketentuan (internal maupun eksternal) yang tidak diindahkan oleh bank syariah sehingga menimbulkan risiko kepatuhan meliputi, di antaranya:

a. Ketentuan mengenai Giro Wajib Minimum, Net Open Position, NonPerforming Financing dan Batas Maksimum Pemberian Pembiayaan.

b. Ketentuan dalam penyediaan produk.

c. Ketantuan dalam pemberian pembiayaan.

d. Ketentuan dalam pelaporan, baik laporan internal, laporan kepada Bank Indonesia, maupun laporan kepada pihak ketiga.

e. Ketentuan perpajakan.

\footnotetext{
${ }^{35}$ Adiwarman A. Karim, Ibid., hal. 275-276. Lihat juga Sri Indah Nikensari, Loc. Cit.

${ }^{36}$ Zainul Arifin, Loc. Cit; Sri Indah Nikensari, Loc. Cit.

${ }^{37}$ Adiwarman A. Karim, Op. Cit., hal. 277.

${ }^{38}$ Sri Indah Nikensari, Loc. Cit.

${ }^{39}$ Zainul Arifin, Loc. Cit; Sri Indah Nikensari, Op. Cit., hal. 195.
} 
f. Ketentuan dalam akad dan kontrak.

g. Fatwa Dewan Syariah Nasional (DSN). ${ }^{40}$

\section{Risiko Modal (Capital Risk).}

Risiko modal adalah risiko yang muncul akibat penurunan kualitas aset, karena adanya kredit macet, yang memaksa bank untuk menerbitkan saham baru dan/ atau menambah setoran modal oleh pemilik, atau mencari investor baru untuk memperbaiki kondisi permodalannya sehingga sesuai dengan ketentuan permodalan. ${ }^{41}$

Salah satu fungsi modal adalah untuk melindungi para penyimpan dana terhadap kerugian yang terjadi pada bank. Jumlah modal yang dibutuhkan untuk melindungi para penyimpan dana berhubungan dengan kualitas dan risiko dari aset bank.

Aset bank dapat diklasifikasikan sebagai aset yang kurang berisiko atau aset yang berisiko. Aset berisiko pada umumnya termasuk tapi tidak terbatas pada investasi atau pembiayaan yang tidak dijamin oleh pemerintah. Sedangkan aset yang kurang berisiko termasuk tapi tidak terbatas pada suratsurat berharga pemerintah atau investasi dan pembiayaan yang dijamin oleh pemerintah.

Risiko modal berkaitan dengan kualitas aset. Bank yang menggunakan sebagian besar dananya untuk mendanai aset yang berisiko perlu memiliki modal penyangga yang besar sebagai sandaran bila kinerja aset-aset itu tidak baik. Tingkat modal itu juga penting untuk menjaga risiko likuiditas. Sumber-sumber risiko yang berkaitan dengan perbankan juga dapat terjadi akibat kehilangan karena pencurian, perampokan, penipuan, atau kecurangan. Sehubungan dengan itu, manajemen harus mengasuransikan beberapa jenis risiko tertentu serta menerapkan sistem pengawasan untuk melindungi kerugian-kerugian tersebut. ${ }^{42}$

\footnotetext{
${ }^{40}$ Adiwarman A. Karim, Op. Cit., hal. 276.

${ }^{41}$ Heri Sudarsono dan Hendi Yogi Prabowo, Op. Cit., hal. 140.

${ }^{42}$ Muhammad, Op. Cit., hal. 358; Nur Kholis, Op. Cit., hal. 103.
} 


\section{E. Pengawasan Risiko Bank Syariah}

Guna meminimalisir risiko yang dapat menimbulkan kerugian bagi bank, maka bank harus menerapkan manajemen risiko, yaitu serangkaian prosedur dan metodologi yang digunakan untuk mengidentifikasi, mengukur, memantau, dan mengendalikan risiko yang timbul dari kegiatan usaha bank.

Dr. Paul Dorey dari Barclays Bank menyatakan bahwa manajemen risiko buka hanya sekedar kemungkinan (probability), tetapi juga masalah informasi atau kekurangan informasi. Mereka percaya bahwa bagaimanapun proses dipilih untuk menerapkan strategi pengelolaan ririko, di mana ada tiga elemen yang merupakan kunci sukses penciptaan dan penerapannya, yaitu: (1) Budaya (culture), dalam hal ini apakah pengurus (the Board of Directors) dan manajemen senior dari lembaga keuangan menerima dan secara aktif memelihara tanggungjawab dalam manajemen risiko dan apakah mereka sebagai tim bekerja sama dan mendemonstrasikan penerimaan tanggungjawab itu; (2) Informasi, yaitu apakah institusi keuangan telah memformulasikan prosedur untuk memperoleh informasi secara sentral, terkoordinir, dan memugkinkan kelompok manajemen membuat keputusan-keputusan yang diketahui secara baik tentang bagaimana mereka mengelola risiko operasional, dan (3) Tindakan, yakni apakah keputusankeputusan pengawasan diambil secara tepat dan secara meyakinkan, dan penerapannya diawasi dengan ketat dan tertib.

Dalam kenyataannya, tidak ada seorangpun dapat membantu menciptakan ketiga faktor tersebut. Hal itu harus diputuskan atau diciptakan oleh manajemen dari institusi masing-masing.

Bank-bank di Indonesia telah diwajibkan untuk menerapkan manajemen risiko secara efektif. Penerapan manajemen risiko tersebut sekurang-kurangnya mencakup pengawasan aktif Dewan Komisaris dan Direksi, kecukupan kebijakan, prosedur dan penetapan limit, kecukupan proses identifikasi, pengukuran, pemantauan dan pengendalian risiko serta sistem informasi manajemen risiko, dan sistem pengendalian intern secara menyeluruh. Penerapan manajemen risiko itu juga harus disesuaikan dengan tujuan, kebijakan usaha, ukuran dan kompleksitas usaha serta kemampuan bank. Bank yang memiliki ukuran dan kompleksitas usaha yang tinggi, wajib menerapkan manajemen risiko sekurang- 
kurangnya untuk empat jenis risiko, yaitu risiko kredit, risiko pasar, risiko likuiditas, dan risiko operasional. ${ }^{43}$

Bank dianggap memiliki ukuran dan kompleksitas usaha yang tinggi antara lain apabila memenuhi salah satu kondisi berikut ini:

1. Bank yang memiliki total aktiva Rp10.000.000.000.000,00 (sepuluh triliun rupiah).

2. Bank yang aktif secara internasional (internatiolity active), yaitu bank yang memiliki kantor cabang di beberapa negara lain atau bank yang merupakan kantor cabang dari bank yang berkantor pusat di luar negeri.

3. Bank yang memiliki 30 (tiga puluh) kantor cabang atau lebih.

4. Bank yang memiliki 150.000 (seratus lima puluh ribu) nasabah atau lebih, dan atau.

5. Bank yang memiliki tingkat keragaman yang tinggi dalam transaksi/produk/jasa. ${ }^{44}$

Sementara itu, Direksi bank bertanggungjawab atas penyusunan dan pelaksanaan kebijakan dan strategi manajemen risiko serta eksposur risiko yang diambil oleh bank secara keseluruhan, pengembangan budaya manajemen risiko, peningkatan kompetensi sumber daya manusia yang terkait dengan manajemen risiko secara independen serta pelaksanaan kaji ulang secara berkala untuk memastikan keakuratan metodologi penilaian risiko, kecukupan implementasi sistem informasi manajemen serta ketepatan kebijakan, prosedur serta penetapan limit risiko. Kebijakan manajemen risiko tersebut harus disetujui dan dievaluasi oleh Dewan Komisaris.

Bank wajib menyampaikan profil risiko secara triwulan kepada Bank Indonesia, yang disampaikan pertama kali untuk posisi laporan Maret 2005. Bank juga wajib menyampaikan laporan kepada Bank Indonesia setiap penerbitan produk dan aktivitas baru. Selain itu, bank juga wajib menyampaikan laporan kepada Bank Indonesia manakala terdapat kondisi yang berpotensi menimbulkan kerugian yang signifikan terhadap kondisi keuangan bank. ${ }^{45}$

\footnotetext{
${ }^{43}$ Zainul Arifin, Op. Cit., hal. 234-235.

${ }^{44}$ Sri Indah Nikensari, Op. Cit., hal. 183.

${ }^{45}$ Zainul Arifin, Op. Cit., hal. 235.
} 


\section{F. Kesimpulan}

Dalam menjalankan kegiatan usahanya perbankan syariah tidak bisa lepas dari berbagai macam risiko, baik yang bersifat sistemik maupun non sistemik. Untuk itu, diperlukan serangkaian manajemen risiko yang jitu. Manajemen risiko merupakan serangkaian prosedur dan metodologi yang digunakan untuk mengidentifikasi, mengukur, memantau, dan mengendalikan risiko yang timbul dari kegiatan usaha bank.

Bank-bank di Indonesia diwajibkan untuk menerapkan manajemen risiko secara efektif. Penerapan manajemen risiko tersebut sekurang-kurangnya mencakup pengawasan aktif Dewan Komisaris dan Direksi, kecukupan kebijakan, prosedur dan penetapan limit, kecukupan proses identifikasi, pengukuran, pemantauan dan pengendalian risiko serta sistem informasi manajemen risiko, dan sistem pengendalian intern secara menyeluruh.

Secara umum, berbagai jenis risiko yang diuraikan di atas dapat dibedakan menjadi dua kelompok besar, yakni risiko yang bersifat sistemik (systemic risk) dan risiko yang bersifat tidak sistemik (unsystemic risk). Risiko yang bersifat sistemik (systemic risk) adalah risiko yang diakibatkan oleh adanya kondisi atau situasi tertentu yang bersifat makro, seperti perubahan situasi politik, perubahan kebijakan ekonomi pemerintah, perubahan situasi pasar, situasi krisis atau resesi, dan sebagainya yang berdampak pada kondisi ekonomi secara umum. Sementara itu, risiko yang bersifat tidak sistemik (unsystemic risk) adalah risiko yang unik, yang melekat pada suatu perusahaan atau bisnis tertentu saja.

\section{DAFTAR PUSTAKA}

Arifin, Zainul. 2006. Dasar-dasar Manajemen Bank Syariah. Jakarta: Alvabet.

Amirullah dan Haris Budiyono. 2004. Pengantar Manajemen. Yogyakarta: Graha Ilmu.

Fahmi dkk, Irham. 2009. Studi Kelayakan Bisnis Teori dan Aplikasi. Bandung: Alfabeta.

Hafidhuddin, Didin dan Hendri Tanjung. 2003. Manajemen Syariah dalam Praktik. Jakarta: Gema Insani Press.

Karim, Adiwarman A. 2008. Bank Syariah Analisis Fiqih dan Kenangan. Jakarta: PT. RajaGrafindo Persada. 
Kholis, Nur. 2006. “Transaksi dalam Ekonomi Islam”, Modul, Yogyakarta: MSI UII.

Muhammad. 2005. Manajemen Bank Syariah. Yogyakarta: UPP AMP YKPN.

Muslich. 2007. Bisnis Syariah Perspektif Mu'amalah dan Manajemen. Yogyakarta: UPP STIM YKPN.

Muttaqien, Dadan dan Fakhruddin Cikman. 2008. Penyelesaian Sengketa Bank Syariah. Yogyakarta: Total Media.

Nikensari, Sri Indah. 2012. Perbankan Syariah Prinsip, Sejarah, dan Aplikasinya. Semarang: Pustaka Rizki Putra.

Partanto, Pius A dan M. Dahlan al Barry tt. Kamus Ilmiah Populer. Surabaya: Penerbit Arkola.

Sinn, Ahmad Ibrahim Abu. 2008. Manajemen Syariah Sebuah Kajian Historis dan Kontemporer. Jakarta: PT. RajaGrafindo Persada.

Sudarsono, Heri dan Hendi Yogi Prabowo. 2006. Istilab-Istilah Bank dan Lembaga Kenangan Syariah. Yogyakarta: UII Press. 